
\title{
28 Research Suare \\ Black Kites on a Flyway Between Western Siberia and the Indian Subcontinent
}

Ivan Literák

University of Veterinary Sciences Brno

Jan Škrábal ( $\square$ skrabalh@seznam.cz)

University of Veterinary Sciences Brno https://orcid.org/0000-0001-9239-0920

Igor V. Karyakin

Sibecocenter

\section{Natalya G. Andreyenkova}

Institute of molecular and cellular biology SB RAS

\section{Sergey V. Vazhov}

Shukshin Altai state University for Humanities and Pedagogy

\section{Research}

Keywords: Milvus migrans migrans, Black-eared Kite, Milvus migrans lineatus, migration, the Himalayas, Karakoram, high elevation, wind.

Posted Date: August 10th, 2021

DOl: https://doi.org/10.21203/rs.3.rs-777325/v1

License: (c) (i) This work is licensed under a Creative Commons Attribution 4.0 International License. Read Full License

Version of Record: A version of this preprint was published at Scientific Reports on April 2nd, 2022. See the published version at https://doi.org/10.1038/s41598-022-09246-1. 


\section{Abstract}

\section{Background}

The Black Kite (Milvus migrans) is one of the most widespread raptors in the World. The Palaearctic is populated by two migrating subspecies, Milvus migrans migrans and Milvus migrans lineatus, in the western and eastern part of this realm, respectively. The intergradation zone of $M . m$. migrans/M. $m$. lineatus covers large areas in-between. Migration routes of M. m. migrans from Europe to Sub-Saharan Africa and the Middle East are well known including large waterbodies as main environmental obstacle.

\section{Methods}

We tagged with GPS/SMS/GPRS telemetry loggers 13 and 6 Black Kite pulli in lowland around Biysk and in mountains around Kosh-Agach.

\section{Results}

Black Kites originating from Biysk migrated through the Western Circum-Himalayan Corridor. Black Kites originating from Kosh-Agach used the Trans-Himalayan Corridor crossing the Himalayas in altitudes of up to $6256 \mathrm{~m}$ asl. The average total distance travelled of Black Kites from both subpopulations was $9166 \mathrm{~m}$ without any significant differences between these subpopulations. Timing of autumn migration varied slightly among individuals in departure date (30 August \pm 9 days) and differed more in arrival date (26 October \pm 92 days). The timing of spring migration varied less in both departure date (17 April \pm 12 days) and arrival date (09 May \pm 14 days). Black Kites from both subpopulations wintered in low elevations of anthropogenic areas of Pakistan and India. Birds wintered on average for 190 days, and the mean area of individual home ranges was $4704 \mathrm{~km}^{2}$. During the breeding period, birds occupied mainly natural or semi-natural habitats in southwestern Siberia, where they spent on average 106 days with an average home range size $3554 \mathrm{~km}^{2}$.

\section{Conclusion}

Black Kites crossing the Himalayas fly and, moreover, stay for hours resting at night in the environment of mountains at altitudes over $5000 \mathrm{~m}$. It seems that the vast breeding territory of Black Kites in the Palearctic realm is connected with the unusual behavioural flexibility of Black Kites to surmount various environmental obstacles on their migration routes.

\section{Introduction}

The Black Kite (Milvus migrans) is one of the most widespread raptors occurring in Eurasia, Africa, and Australia $(1,2)$. It shows unique ecological flexibility and can inhabit many habitats, including humanaffected landscapes, using variable food sources as an opportunistic predator and scavenger (3-6). The Palaearctic is populated by two subspecies, Milvus migrans migrans (7-10) and Milvus migrans lineatus in the western and eastern part of this realm, respectively (7-10). Indian Subcontinent and Indo-China are 
populated by Milvus migrans govinda; Australia, and the adjacent islands by Milvus migrans affinis. Milvus migrans formosanus inhabits the eastern part of China, Taiwan, and Hainan. Africa is populated by subspecies Milvus migrans parasitus Milvus migrans aegyptius.

The ranges of the Palaearctic subspecies contact each other with an opportunity for mutual hybridisations. The intergradation zone of M. m. migrans/M. m. lineatus covers large areas of Eastern Europe, Kazakhstan, and West Siberia and is gradually expanding $(1,11-15)$. The most active is the westward expansion so that the birds with the characters of $M$. $m$. lineatus already occur in Iberian Peninsula (16). Black Kites of these two subspecies seem to cross freely since birds in the intergradation zone exhibit a whole range of intermediate characters (13). Moreover, it is supposed that the M. $m$. migrans/M. m. lineatus mixed population meets the M. m. govinda in the Hindu Kush in Afghanistan and Pakistan; thus, the intergradation zone between all the three Eurasian subspecies may exist (13).

The Palaearctic M. m. migrans and $M$. m. lineatus are seasonal migrants. M. m. migrans from Europe winter in Sub-Saharan Africa and the Middle East. Its migration routes are well known $(6,17,18)$. The migration of $M$. m. lineatus is poorly studied. Based on the phenotypes of observed birds, M. m. lineatus overwinters in India, Indo-China, and China (19). Black Kites (pure M. m. lineatus?) from the eastern part of Mongolia overwintered in north-eastern India and Myanmar $(20,21)$. M. m. govinda breeding on the Indian subcontinent is sedentary, and during winter, shares the territory with the Black Kites arriving from the eastern Palaearctic $(2,22)$. Japan is inhabited by a nearly sedentary $M$. $m$. lineatus population, which seems to undertake seasonal migrations confined to the Japanese Archipelago (23). M. m. affinis migrates seasonally within the Australian continent (24). M. m. aegyptius migrate south to the East African coast, and M. m. parasitus migrates from South Africa to Uganda $(25,26)$.

Telemetry data suggest that immature $M . m$. migrans do not return to their natal area after first overwintering and may keep outside until maturity, moving long within the nesting and overwintering territories $(18,27)$. Formations of large summer aggregations of immature Black Kites were reported from Siberia $(28,29)$. M. m. migrans start nesting when 3-5 years old (30). Natal dispersal of kites was studied mainly in $M$. m. migrans. These birds tend to return for nesting to the natal area. Natal philopatry is relatively high ( $5 \mathrm{~km}$ on average, however, it may exceed $100 \mathrm{~km}$ ) (30). Recently, a distance of $198 \mathrm{~km}$ between the natal nest and a place of own breeding was documented in the Czech Republic (31). Breeding philopatry (philopatry of birds after their first breeding) of adult M. m. migrans and adult birds from intergradation zone $M$. m. migrans/M. m. linaetus were strongly associated with their previous nesting territories, preferring to return each year $(29,30)$.

Migration routes and winter quarters mainly remained the same in individual $M . m$. migrans in the first three years of their life (18). Surprisingly for birds in 2cy, it was found that summer quarters occurred at lower latitudes than predicted and a substantial proportion of birds of this age remained in their African winter quarters. Some birds in their 3cy returned to spend the summer period in the natal area, but many of these birds remained at lower latitudes north of their winter quarters. Similar behaviour has been described in some other raptors (Circaetus gallicus, Pernis apivorus) migrating from Europe to Africa and 
back $(32,33)$. Circannual variations in the movement patterns of $M$. m. migrans have been extensively reviewed (6). During migration, tens of thousands of $M$. m. migrans are observed migrating across the Straits of Gibraltar, along the eastern coast of the Black Sea and in the Middle East; while, substantial numbers cross the central Mediterranean (including Italy, Sicily, and Tunisia) and the Bosporus $(6,34)$. Few birds cross the Mediterranean Sea between the Peloponnese, Crete, and Libya (6). The crossing of large water bodies of the Mediterranean Sea and the Black Sea seems to be challenging environmental obstacles for M. m. migrans on the flyway from Europe to Africa $(6,35)$.

Black Kites, supposedly originating from the intergradation zone between $M . m$. migrans and $M . m$. linetus migrate traditionally to winter in Iraq, Iran, and western Pakistan (11). Siberian M. m. lineatus migrate to winter in the Indian subcontinent regarding the $18^{\circ}$ Northern Latitude, Myanmar, Indochina, and southern China (11). Recently, some individuals of $M$. m. lineatus of unknown origin were also observed wintering in Kazakhstan (36-38).

Migration routes of Black Kites from the Siberian part of Russia are mainly unknown. Some observations of Black Kites in autumn around Novosibirsk and the Kuznetsky Alatau Mountains indicated their direction of autumn migration to Kazakhstan, and aggregations of Black Kites on their autumn migration route through Kazakhstan were reported from Chokpak Pass (39-41). Between 2014 and 2018, Black Kites called Black-eared Kites (unfortunately, not specified if Kites originating from the intergradation zone between $M . m$. migrans and $M$. $m$. lineatus or pure $M$. $m$. lineatus) had been tagged with GPS transmitters at the landfill in Dehli, India (42). These pre-adult and adult Kites tagged in winter were tracked to reveal their migratory flyways. Kites migrated for $3300-4800 \mathrm{~km}$ along the narrow corridor between Dehli (winter quarters) and southern Siberia and western Mongolia (summer including supposedly breeding quarters), crossing the Himalayas at elevations up to more than $6500 \mathrm{~m}$ a.s.l. by the $\mathrm{K} 2$ of the Karakoram Range and travelled long periods at elevations above $3500 \mathrm{~m}$. a.s.l. Previously, Black Kites were regularly observed during migration at various watch-sites in the Himalayan ridge in northwestern India, Nepal and the Tibetian Autonomous Region, western China (43).

Among atmospheric conditions, wind is known to strongly influence the speed of migration specifically during long-distance migration and overcoming of natural barriers (44-46). Flying with wind assistance may induce a decision to depart (47). Several studies have shown that both flapping and soaring migrants travel significantly faster when flying with tailwinds and are hindered by headwind and crosswinds $(48,49)$. Recent technological advances have made it possible to use tracking technology to record the flight path of wild birds and then determine from weather records the atmospheric conditions at the locations where the birds were recorded (50). This approach estimates key metrics needed for understanding the effect of wind on birds under natural conditions (46).

We studied Black Kites fledged in southwestern Siberia, Russia, which were tagged as pulli with GPS transmitters on nests in a) lowland area near Biysk, Altai Krai populated by Kites from the intergradation zone between M. m. migrans and M. m. lineatus, b) in a mountainous area near Kosh-Agach, Altai Republic populated by supposedly pure $M$. $m$. lineatus. The aims of the study were a) to reveal and to 
compare migration routes of Kites from these two populations, b) to define the timing of autumn and spring migrations, c) to characterise sizes of their post-fledging area, home ranges in wintering quarters and summering (breeding) ranges, and d) to study in details, including weather conditions, the way how Kites crossed the extremely high elevations of the Himalayas as the leading environmental obstacle on their migration.

\section{Materials And Methods}

\section{Birds}

In total, 19 Black Kites (11 females, 8 males) from breeding populations in Western Siberia, Russia, were investigated in this study. Kites originated from two spatially separated breeding subpopulations. One subpopulation represents birds hatched in lowland around Biysk (Altai Krai), the second subpopulation represents birds hatched in the mountains around Kosh-Agach (Altai Republic) near the Mongolian border (Table 1).

\section{DNA examination}

Contour pin feathers (newly grown feathers, full of blood) were collected from the lower part of a chick body) and stored in $96 \%$ ethanol. The total DNA was isolated using the ExtractDNA Blood kit (Evrogene, Russia). The sex of tagged birds was determined by a method by Suh et al. (2011). A 699 bp fragment of the mitochondrial $c y t B$ gene was analysed to identify haplotypes (51).The $c y t B$ mitochondrial gene fragment (924 bp) was amplified using F3 (5'-CCACCCCATCCTCAAAATAA-3') and R8

(5'ATTGTGCGCTGTTTGGACTT-3'). We sequenced PCR fragments in both directions using a 3500 Genetic Analyser capillary sequencer (Applied Biosystems, USA) and aligned resulting sequences using the Vector NTI software (Thermo Fisher Scientific). In order to exclude contamination, operations with genomic DNA and with PCR products were performed in different rooms. In unclear cases, PCR and sequencing were repeated.

\section{Satellite telemetry devices}

Black Kites (pulli) were fitted with telemetry loggers in nests in 2018 (subpopulation A) and 2019 (subpopulation B). Loggers equipped with solar panels (20 g; Ecotone, Poland, and Ornitela, Lithuania; www.ecotone.pl, www.ornitela.com, respectively) were used to track the birds. Loggers were fitted onto the backs of the birds using harnesses (backpacks) consisting of a $6 \mathrm{~mm}$ Teflon ribbon encircling the body by two loops around the bases of the wings and joined in front of the breastbone. Loggers function in GPS (Global Position System)/GSM (Global System for Mobile Communication) systems. The GPS positions of the birds were collected according to individual settings (usually one position fixed per 1-6h). They were sent as SMS (Short Message Service) text messages by local mobile operators to the Ecotone and Ornitela Centers in Poland and Lithuania, respectively, where they were saved and archived. The coordinates of bird positions were analysed using GIS and the software ArcGIS 10.1 (Esri, Redlands, CA, USA) and QGIS (www.qgis.org). 


\section{Data processing, migration characteristics}

We processed positional data (coordinates) from studied birds for each bird individually. These data were separated into yearlong modules from 01.07.20XY (in the first year from the date of tagging) to 30.06.20XY+1. The number of modules depends on the lifespan of each bird. We calculated the total distance travelled within the yearlong period and the number of temporary settlements areas (TSA) from these modules. We defined total distance travelled as distances between roosting places connected chronologically (daily local movements were not calculated within the migration movement $=$ total distance travelled).

We defined TSA as a preferred place where a bird stayed for $>10$ nights within $80 \mathrm{~km} 2$. This template size was based on roost locations distributed within a 10-km diameter over 10 days, thus, all falling within $80 \mathrm{~km}^{2}$ (18). Spring (pre-breeding) and autumn (post-breeding) migrations separate the winter and summer period. We defined the beginning of those migrations as a day when the bird left the ground for good. The end is defined as a day when the bird reached the summer or winter destination. During both migrations, birds tend to use stopovers, defined as a day with less than $50 \mathrm{~km}$ of a directed fight (42). The size of the post-fledging area (PFA), winter and summer grounds (home ranges) between migrations were calculated as a Kernel density estimate (KDE) 95\%. The Himalayas flight-over was defined as the period of migration between the first and last day of migration with coordinates recorded by the foothill of the Himalayas with at least one coordinate recorded at over $5000 \mathrm{~m}$ above the sea level. We calculated the length of trajectory segments leading parallelly along mountain ridges during the flight-over and compared them with the overall distance travelled during the flight over the Himalayas.

We defined checkpoints W1, W2 and W3 as night positions where birds stayed on 31 January of their 2cy (second calendar year), 3cy and 4cy, respectively. It represents where birds were wintering during this date during the first, second and third winter. We defined checkpoints S1, S2 and S3 as positions where birds stayed during the breeding period on 30 June of their 2cy, 3cy and 4cy, respectively. We used the positions during S1, S2, S3, W1, W2 and W3 to compare migration characteristics of individual birds between years of their life span and compare migrations among individual birds during the first, second and third years of their life. Natal dispersal distance was defined as the distance (using a straight line) between the birthplace (natal nest) and breeding place (30).

\section{Meteorological data}

Elevation data was downloaded from the mapping and analysing platform www.databasin.org " 30 arcsecond DEM of Asia" as a digital elevation model (DEM).

Weather data (wind, temperature and humidity) were obtained from the NCEP/DOE Reanalysis II dataset, using the RNCEP package (52) for the R-software. Weather data of flight over the Himalayas were extracted for each coordinate in real-time, and pressure level of $700 \mathrm{hPa}$ corresponding to an altitude between $2300 \mathrm{~m}$ and $3150 \mathrm{~m}$. Airspeed, flow-assistance and side wind were calculated by function NCEP.tailwind using RNCEP package, which calculates flow-assistance and forward and sideways 
movement according to equation Tailwind (Tailwind $=$ wind speed * $\cos (a)$, where $\alpha$ is the angle of the wind from the direction of travel). Equation Tailwind considers flow-assistance to be the component of the flow moving parallel to the specified direction (tailwind), with negative values indicating flows against the specified direction (headwind). Negative values of side wind speed represent the Eastern wind; positive values represent Western wind. We have extracted the weather data for coordinates recorded during post-breeding $(n=1090)$ and pre-breeding $(n=1310)$ migration over the Himalayas. We excluded coordinates recorded while roosting from the dataset.

\section{Statistical analysis}

We performed the Mann-Whitney $U$ test for testing the differences in pre-breeding and post-breeding migration and home-range characteristics and the pre-breeding and post-breeding Himalaya's flight-over characteristics. To assess the difference in total distance travelled, number of TSA, and the size of home ranges in summer and winter quarters over the years, we performed Kruskal-Wallis ANOVA test. Before any statistical comparison, we run the Shapiro-Wilk test for normality to assess the data distribution. To assess the effect of weather on bird's movement across the Himalayas, we used linear mixed models (LMMs) in R (53) using the 'Ime4' package (54) to analyse the following dependent variables: bird ground speed and airspeed, in relation to flow-assistance and side wind during the flight over the Himalayas. We used LMM with bird ID as a random effect (as individuals could be tracked over multiple years). Only birds with telemetry loggers Ornitela, which flew over the Himalayas, were included in the LMM (K14 $\mathrm{K} 19)$ due to the high frequency of coordinates recording. The best supported LMM model was selected according to the lowest Akaike's information criterion for a small sample size (AICc). A difference in AICc $(\triangle \mathrm{AIC})$ between a model with a predictor and an intercept-only model greater than two was considered strong evidence for a particular model (55). All statistical tests were performed using an a-value of $5 \%$, and all mean values are presented ( \pm standard deviation; SD) unless stated otherwise.

\section{Results}

\section{cytB haplotypes}

Black Kites from Biysk belonged to haplogroup $A$ (haplotypes $A 3$ and $A 4$ ) and haplogroup $B$ (haplotypes B6, B6.1, B14, B19 and B19.1). Three families and 8 families had haplogroups A and B, respectively (Table 1). All Black Kites (5 families) from Kosh-Agach belonged to haplogroup $B$ (haplotypes B6, B14, B19 and B19.1).

\section{Migration routes and total distance travelled}

Black Kites originating from Biysk migrated through the Western Circum-Himalayan Corridor (Figure 1). These birds flew through eastern Kazakhstan, Kyrgyzstan, Tajikistan and eastern Afghanistan to winter, mainly in northern and southern Pakistan and western India. After winter, birds flew over the same migration corridor back to Biysk area. Unlike Kites from Biysk, Black Kites originating from Kosh-Agach used a different migration route (Figure1). These birds flew over Tian Shan, and the Taklamakan Desert 
in China, followed by Trans-Karakoram flight-over thought Jammu and Kashmir to winter in northern and western India and eastern Pakistan. After winter, birds flew over the same corridor back to Kosh-Agach area.

The average total distance travelled of birds from both subpopulations in the first year was $9191 \mathrm{~km}$ (ranging from 6431 to $12478 \mathrm{~km}$ ). During the first year, birds used on average 4 TSAs (ranging from 2 6). During the second year, birds travelled on an average total distance of $9121 \mathrm{~km}$ (ranging from 7422 - $11268 \mathrm{~km}$ ) using 5 TSAs (ranging from 4-7). The average total distance travelled in the third year was 6839 (ranging from $6594-7$ 084) using 5 TSA (ranging from 4 -5) (Table 2).

Five tagged birds survived and were tracked for multiple years. For those individuals, we compared the differences in the total distance travelled and the number of used TSAs. We found no significant difference in the total distance travelled $(P>0,05)$ nor the number of TSA $(P>0,05)$ used among the years. We also tested the difference in total distance travelled, and the number of TSA used between the two subpopulations without any significant results $(P>0,05)$.

\section{Timing of autumn and spring migrations}

Timing of autumn migration varied slightly among individuals in departure date (30 August \pm 9 days) and differed more in arrival date (26 October \pm 92 days). The timing of spring migration varied less in both departure date (17 April \pm 12 days) and arrival date (09 May \pm 14 days). The tagged kites travelled relatively fast, completing a $2535-4842 \mathrm{~km}$ journey in 10-94 days, progressing by $62-253 \mathrm{~km} /$ day, with significantly faster speeds and lower need to rest in the pre-breeding migration (Table 3 ).

\section{Post-fledging area and home ranges in winter and summer}

The post-fledging area of tagged Kites varied from $1.7 \mathrm{~km}^{2}$ to $1567 \mathrm{~km}^{2}$ with a mean of $396 \pm 432 \mathrm{~km}^{2}$ (Table 4). Some birds left the nest and flew straightforward to the winter quarters. Others birds explored the area around the nest and departed for autumn migration with a slight delay. Black Kites from both subpopulations wintered in Indian Subcontinent in low elevations of anthropogenic areas of Pakistan and India (Figures 1 and 2). No bird remained in the Indian subcontinent during summer periods (Figure 3). Birds wintered on average for 190 days, and the mean area of individual home ranges was $4704 \mathrm{~km}^{2}$ (Table 4). On the contrary, during the breeding period, birds occupied mainly natural or semi-natural habitats south-western Siberia, where they spent on average 106 days with an average home range size 3 $554 \mathrm{~km}^{2}$ (Figures 1 and 2; Table 4). No bird remained in Siberia during the winter period (Figure 3). Although the mean area of home ranges was slightly smaller during the breeding season than in the nonbreeding winter period, we found no statistical difference in the spatial use $(p>0.05)$. Five tagged Black Kites survived and were tracked for multiple years (Table 4). For those individuals, we compared the differences in the area size of home ranges in the breeding (summer quarters) and nonbreeding season (winter quarters). We found no difference in spatial use over the years in neither the winter quarters $(p>0.05)$ or summer quarters $(p>0.05)$. 
Timing of post-breeding and pre-breeding flight over Himalayas varied slightly among individuals in departure dates (19 September \pm 11 days; 28 April \pm 7 days) and arrival dates (20 September \pm 11 days; 29 April \pm 7 days). Black Kites originating from Koch-Agar travelled relatively fast, flying over the Himalayas (on average $571 \mathrm{~km}$ ) in 2 days, progressing with average active speed of $31.7 \mathrm{~km}$ per travelling hour, flying from 6 to 10 hours per day. Active speed and number of traveling hours were slightly higher during pre-breeding flight-over. During the crossing of the Himalayas birds roosted for one night in average altitude of $4246 \mathrm{~m}$ asl, ranging from 1577 to $5171 \mathrm{~m}$ asl (Table 5, Figure 3).

Weather conditions significantly varied during the pre-breeding and post-breeding Himalaya flight-overs (Table 5). Noticeable was the difference in the tailwind speed, sidewind speed and percentage of parallel flight along the mountain ridge. While during the post-breeding flight-over, birds faced mostly a headwind and preferred to fly perpendicularly to mountain ridges and mountain valleys, on their pre-breeding flightover, birds flew with a tailwind and preferred to fly parallelly along the mountain ridges and mountain valleys (Figure 4). The ground speed and airspeed of birds flying over the Himalayas in autumn were positively related to tailwind and side wind speed (Table 6a). Therefore, both winds increased the bird groundspeed and airspeed (Figures $4 a$ and $5 a$ ). During the pre-breeding migration, the tailwind had a greater positive effect on both the ground- and airspeed of bird, which led to a higher speed increase. However, the side wind had a negative effect (Table 6b). Therefore, bird groundspeed and airspeed increased with tailwind and degreasing with stronger side wind during the pre-breeding flight over the Himalayas (Figure $4 b$ and $5 b$ ).

\section{Natal dispersal distance}

Breeding behaviour was evident according to GPS positions in one black kite male (K 10) in its age of 3 years (4cy). Its supposed nest was in a distance of $14.6 \mathrm{~km}$ from its natal nest. The other male of this age or younger black kites showed no signs of breeding.

\section{Discussion}

\section{Subspecies status ef examined Black Kites and their migration routes}

We found different sets of cytB haplotypes in Black Kites from Biysk and Black Kites from Upper Altai close to Kosh-Agach. While in Kosh-Agach, the haplotypes were characteristic of $M$. $m$. lineatus, in the vicinity of Biysk, the haplotypes were characteristic for both subspecies M. m. migrans and M. m. lineatus, indicating a hybrid population from the intergradation zone between $M . m$. migrans and $M . m$. lineatus $(51,56)$. Lindholm and Forsten $(57)$ were aimed at subspecies determination of Black Kites in Altai Krai (Barnaul area) and Altai Republic (area of Kosh-Agach) according to morphological features. They found that birds in the lowlands of Altai Krai, on average, were different from those in the higher 
country of the Altai Republic. Black Kites from the lowlands of Altai Krai had some features of $M . m$. migrans (i.e., birds originated from the intergradation zone between $M$. m. migrans and M. m. lineatus). Black Kites from Altai were quite similar to the easternmost typical lineatus and were placed in that taxon (i.e., M. m. lineatus). This conclusion fits well with our observations, and it is consistent with our cytB haplotype results. We consider Black Kites tagged in Byisk as birds from the intergradation zone between M. m. migrans and M. m. lineatus and Black Kites tagged in Kosh-Agach as birds belonging to M. $m$. lineatus. Deep genomic study of Black Kites from various parts of their breeding area is needed to solve the genetic structure of their populations and hence, their species/subspecies status.

Raptors of several species were observed to migrate across the Himalayan region, and based on all data available, there were characterised four movement patterns of raptor migrating in this area: 1) Western Circum-Himalayan Corridor, 2) Eastern Circum-Himalayan Corridor, 3) East-to-West Southern Corridor and

4) Trans-Himalayan Corridor (43). We demonstrated that Black kites from Biysk (birds from intergradation zone between M. m. migrans and M. m. lineatus) used Western Circum-Himalayan Corridor and Black Kites from Kosh-Agach (M. m. lineatus) used Trans-Himalayan Corridor. Birds shared wintering ranges in the Indian subcontinent from both populations. We consider that the genetic background of the migration behaviour of Black Kites is strong, and the uniform behaviour of tracked birds from both studied subpopulations with different genetic history supports this hypothesis (see also Sergio et al. (17)). Nevertheless, variable routes of raptors (Peregrines, Falco peregrinus) migrating from Siberia to South Asia were demonstrated even if they had the exact genetic origin (58). Peregrines from a relatively small area close to the Popinga River, northern Siberia, used Western Circum-Himalayan Corridor (to winter in south Pakistan), Eastern Circum-Himalayan Corridor (to winter in Myanmar), and Trans-Himalayan Corridor (to winter in north India and Bangladesh).

\section{Bird (including Black Kites) migration over high altitudes in the Himalayas}

High-altitude flights of birds over the Himalayas is a highly challenging feat of performance underpinned by several specialised physiological traits. Flapping birds like Bar-headed Goose (Anser indicus) and Ruddy Shelduck (Tadorna ferruginea) can reach high altitudes during their migration across the Himalayas and Tibetian plateau because they can support the metabolic costs of flight as the lowdensity air becomes extremely hypoxic $(59,60)$. Like other migrating (soaring) birds, they may occasionally use updraft wind assistance to help offset flight cost (61). However, they experience periods of intense flapping flight that require extremely high heart rates, wing-beat frequencies, and metabolic power, such as during level flight at high elevation or during climbs that are not assisted by wind $(59,62)$. Bar-headed Geese can pass over the Himalayas in one day, typically climbing between 4000 and $6000 \mathrm{~m}$ in 7-8 hours, with a majority of climbing flights occurring during the night and early morning (63). Barheaded Geese and Ruddy Shelducks fly up to $6443 \mathrm{~m}$ and up to $6800 \mathrm{~m}$ altitudes, respectively, but more commonly, both species remain below $5600 \mathrm{~m}(60,62)$. Birds of both species selected an optimum flyway to avoid peaks and higher speed winds (they did not fly in specific wind speeds or directions during migratory flights or climbs) $(60,63)$. Bar-headed Geese typically travel through valleys of the 
Himalayas and not over summits. Their maximum flight altitudes were $7290 \mathrm{~m}$, and $6540 \mathrm{~m}$ for southbound and northbound individuals, respectively (61), Autumn migration of Bar-headed Geese breeding in Qinghai Lake, China and wintering in Indian lowland lasted for 50-90 days, and on their routes, the geese used 3-4 stopover sites in wetlands at Tibetian plateau and crossed the Himalayas in approx. $6000 \mathrm{~m}$ altitude (64).

Recently, it was revealed that most of the ducks wintering in India pass over the Himalayas (65). Flapping ducks as Eurasian Wigeon (Anas penelope), Gadwall (Anas strepera), Northern Pintail (Anas acuta), Nothern Shoveler (Anas clypeata), and Garganey (Anas querquedula) usually flew overpasses at altitudes of $5070 \mathrm{~m}$ (Niti Pass) and $4310 \mathrm{~m}$ (Nathu Pass). However, they were able to reach altitudes up $6830 \mathrm{~m}$ (Northern Shoveler) and $6930 \mathrm{~m}$ (Garganey). Before flying over the Himalayas, the ducks stopped at wetlands to replenish their fat reserves. Other flapping birds like Demoiselle Cranes (Anthropoides virgo) and some waders can also cross the Himalayas in high elevations during migrations. One tagged Demoiselle Crane avoided the Himalayas on its migration to the south from summering range in Kazakhstan, and it flew using western route over Hindu Kush, Pamirs, and Tien Shan wintering ground in India, three other Cranes, tagged in Mongolia passed the Himalayas at elevations over $5000 \mathrm{~m}$. They crossed the Tibetian Plateau within three days to reach wintering grounds in Indian lowland (66). Using geolocators and satellite tracking devices, it has been very recently demonstrated that waders Common Redshank (Tringa totanus) and Whimbrel (Numenius phaeopus) could also directly fly over the Himalayas on their migration (Li et al. 2020). Common Redshanks were flying at altitudes of potentially 3000-5000 m. Both Redshanks and Whimbrels benefited from wind assistance during migratory flights. The study suggested that the Himalayan mountain range may be less of a barrier than assumed.

Raptors are large or medium-sized land birds that primarily use soaring-gliding flight during migration (67). Soaring (up draught-assisted non-flapping flight) is an energetically efficient form of flight, and many long-distance migrants are so-called obligate soaring migrants (43). Up draught necessary for soaring flight includes thermals (pockets of warm rising air) and deflection (orographic) updraughts that occur when horizontal winds strike surface discontinuities, including mountains. The high-altitude terrain of the Himalayas precludes this type of pathway, and hence it is used by raptors (43). However, some raptors, especially falcons, use flapping flight on their migration across the Himalayas (58).

Unfortunately, detailed studies using telemetry devices on raptors crossing the Himalayas are scarce. A study aimed at the Steppe Eagle (Aquila nipalensis) revealed that a bird tagged on nest in Mongolia migrated to winter in a mountainous area in Uttarakhand State, India (68). It flew during migration up to $200 \mathrm{~m}$ relative to the ground, occasionally reached more than $1600 \mathrm{~m}$. The highest altitude recorded was $7200 \mathrm{~m}$ asl. The altitude of the roost site on the day before the crossing of the Great Himalayas was 4630 $\mathrm{m}$, and after the crossing, the eagle roosted at $4530 \mathrm{~m}$.

We can compare our results mainly with a recent study aimed at Black Kites fitted with telemetry loggers in Dehli, India (42). It seems that Black kites tagged in Dehli originated, similarly like in our study, to two different population: birds that used Western Circum-Himalayan Corridor may belong to Black kites originating from the intergradation zone between $M . m$. migrans and M. m. lineatus, birds that used 
Trans-Himalayan Corridor may belong to M. $m$. lineatus. Migration routes of these birds were distinct in our study as well as like in a study by Kumar et al. (42). The birds originating from Upper Altai (KoshAgach) crossed the Himalayas over Tian Shan Mts, Taklamakan Desert, and Karakoram Mts like the main portion of Black Kites tagged in Dehli.

These birds crossed the Himalayas in extremely high elevation up to $6281 \mathrm{~m}$ asl and travelled long periods at elevations above $3500 \mathrm{~m}$. Birds flew across the Himalayas for two days with a single stop to roost at elevations between 1644 to $5448 \mathrm{~m}$ asl.

It seems that Black Kites crossing the Himalayas may have physiological adaptations that remain to be investigated. They fly and, moreover, stay for hours resting at night in the environment of mountains at altitudes over $5000 \mathrm{~m}$ with variable wind speed and direction, where the air density and partial pressure of oxygen is roughly half of that at sea level $(59,69)$. At the same time, the temperature can be very low, well below freezing year-round, which could require additional metabolic energy for thermogenesis.

Maintaining water balance during flight should also be a major challenge in the dry air at high altitudes $(59,69)$.

\section{Behavioural flexibility of immature Black Kites to stay somewhere in summer}

Tagged Black Kites M. m. migrans from Europe wintered in sub-Saharan Africa north of the equator throughout the belt from Senegal and Gambia to Ethiopia in East Africa (18). Some of these Black Kites remained in tropical Africa during their first summer. Other birds moved north but to substantially lower altitudes than those of their natal areas. During the second year, all tagged Black Kites M. m. migrans wintered again in tropical sub-Saharan Africa. Their summer quarters were located north of the winter quarters, but no birds stayed during the summer in the natal areas. One tracked bird returned to its natal area and bred at the age of three years. Immatures Black Kites M. m. migrans stayed in summers in areas used for wintering or somewhere between winter quarter and natal areas. Surprisingly, no such behaviour was observed in tagged Black Kites from western Siberia, no matter if these birds originated from the population in Biysk or Kosh-Agach. These Black Kites regularly returned from wintering quarter in Indian Subcontinent to natal areas or more north to stay there in summer. It seems that high behavioural flexibility is apparent during summer stays of immature Black Kites.

In a previous study, Kumar et al. (42) reported that home ranges of Black Kites fitted with telemetry loggers in Dehli were larger during the breeding season than home ranges during the nonbreeding season using KDE $99 \%$ for the home range calculation. Our paper used for the home range size calculation KDE $95 \%$. Unlike Kumar et al. (42), we found no difference in the size of the home range during the breeding and nonbreeding seasons.

\section{Environmental influence on migration}

Route configuration of Black Kites crossing the Himalayas seemed to be shaped by dominant wind support and barrier avoidance (42). Black Kites perform circular soaring in areas of higher predicted 
thermal uplift and linear soaring in areas of higher predicted orographic uplift velocity (70). During the pre-breeding flight over Himalayas birds tent to fly parallelly along with the mountain ranges, through the mountain valleys using the up-lifting anabatic winds for soaring up to high altitudes and gliding with the possible strong south valley tailwinds (71). During the period of pre-breeding migration (from the end of April to the beginning of May, which correspond to the timing of spring migration of tagged Black Kites) with the warmest and driest surface condition, great ascending thermals are forming, creating a great opportunity for soaring birds to glide over Himalayas (72). While flying north along the mountain ridges, side wind, that mostly blows from the west (71), can break over the ridge creating a lee wind perpendicular to bird direction, that may have a negative effect on the birds' speed as the bird has to angle towards the sidewind (as shown by our results). In contrast with the pre-breeding Himalayas flight over, during the post-breeding Himalayas flight over bird tent to fly directly across the mountain ranges.

We assume that birds used thermals to stay as high as possible to glid along or against the lee winds to avoid the strong headwinds of the valley breeze (71). We found that Black Kites increased more their ground speed and less their airspeed when tailwinds prevailed. For soaring migrants, reducing airspeed under tailwinds allows the birds to attain low sink rate and by that to cover larger distances while decreasing the risk of reaching the ground or switching to energy-expensive flapping flight (73). However, during pre-breeding Himalayas flight over, birds noticeable increased their airspeed even during strong tailwind. We assume that this behaviour is caused by the abundance of great ascending thermals. Bird can therefore afford to increase its airspeed on the expense of higher sink rate in order to quickly pass the Himalaya barrier. We moreover found an asymmetric response of the birds to side wind, compensating when flying north towards the summer ground and drifting when flying south heading the winter quarters. Groundspeed increased in relation to side wind from the west during the post-breeding flight over and under easterly side wind during pre-breeding flight over. Bird response to crosswind was asymmetrical in relation to side wind and flight direction.

Effect of favourable weather conditions on the spring (pre-breeding) migration support our results. We found the spring migration to be significantly shorter in comparison with autumn (post-breeding) migration. Duration of the Himalayan flight-over was found to be the same, although the groundspeed was higher in pre-breeding flight-over, meaning that birds flying over the Himalayas on their way from winter quarters had a higher speed relative to the ground. Birds had similar speed relative to the air during both flight overs. Hence the wind played a major role in the overall speed during the flight-over. For aerial migrants, wind support can reduce both energy and time cost of migration considerably (74). A stronger tailwind that increases the birds' speed eases the Himalaya flight-over. Birds are less exhausted from the Himalayas flight over and arrive at summer destination much faster. During autumn migration, the weather conditions were less favourable, which reflected in the number of days spent in stopovers (mainly by the foothills of the Himalayas) and the overall duration of migration.

\section{High behavioural flexibility of Black Kites to surmount environmental obstacles}


The challenging environmental obstacles for Black Kites M. m. migrans migrating to winter in Africa are crossing large water bodies (35). Most migrating Black Kites $M$. m. migrans are reluctant to fly over large water bodies and cross transcontinental boundaries over the Strait of Gibraltar, the Bosporus Strait, the Dardanelle Strait and the Bab-al-Mandeb Strait $(6,18,75)$. However, some birds use unusual routes of migrating over large water bodies of the Mediterranean Sea and the Black Sea from Europe to Africa and from Europe to the Middle East. Raptors perform a soaring-gliding flight behaviour exploiting rising thermals and ridge lifts overland to reduce energetic expense. However, during migration, when crossing large water bodies, thermal updrafts are weak, and birds mainly use flapping (powered) flight, increasing both energy consumption and mortality risk (67). Black Kites crossing the large water bodies have to use flapping flight $(18,35)$. All routes over large water bodies are suboptimal for Black Kites, and they are supposedly used only by a minority of Black Kites originating from Europe since, for some of them, this route could be fatally unsuccessful (18). From this perspective, unusual observations of Black Kites on islands in the Atlantic Ocean, far from breeding territories and usual migration routes, are remarkable (76-78). One case of a long journey over the Red Sea was facilitated by the transport of the bird on board a cargo ship (27).

The challenging environmental obstacles for Black Kites $M$. $m$. lineatus migrating to winter in Indian Subcontinent is the crossing of the main Himalayan ridge, which was discussed above. It seems that the vast breeding territory of Black Kites in the Palearctic realm is connected with the unusual behavioural flexibility of Black Kites to surmount various environmental obstacles on their migration routes.

This high behavioural flexibility may also elucidate a new important wintering area for Black Kites in the Middle East. Black Kites with $M$. m. lineatus features were recorded for the first time in the Levant area in Syria (and perhaps also in Lebanon) during the beginning of the second half of the twentieth century (79, 80). Novel observations of the communal roosting of Black Kites during the winter months have been reported in south-eastern Europe, Egypt, and Turkey; however, their taxonomic subspecies status was not mainly investigated (81-86). Now, the Black Kite is the most common wintering raptor in Israel, and a proportion of kites wintering in Israel showed morphological characteristics of $M$. $m$. lineatus, likely representing the western outpost of wintering $M$. m. lineatus (87). Alternatively, these individuals may comprise birds from the broad intergradation zone between $M$. m. migrans and $M$. m. lineatus (88). It now appears that Black Kites with $M$. $m$. lineatus features supposedly originated from a large intergradation zone between M. m. migrans and M. m. lineatus can be found anywhere in Europe west of Russia (16). Recent data on numerous wintering of Black Kites in Georgia in an area of the Black Sea Basin correspond well with these data (89). Moreover, Black Kites with M. m. lineatus features can be found migrating from southern and eastern Africa as documented in South Africa on 3 November 1972 and Ethiopia on 18 November $2011(90,91)$. No significant environmental obstacles seem to complicate the migration of these Black Kites with features of $M$. $m$. lineatus (birds supposedly originated from the intergradation zone between $M$. m. migrans and $M$. m. linetus, preferably from the European part of Russia). 


\section{Conclusion}

By telemetry research and DNA analyse of Black Kites from Western Siberia we found differences in subpopulations of Black Kites from Upper Altai close to Kosh-Agach and Black Kites from Biysk, pointing at the intergradation zone between $M . m$. migrans and $M$. m. lineatus and revealing their migration routes. Black Kites $M$. m. lineatus migrating to winter in Indian Subcontinent are challenged by the crossing of the main Himalayan ridge. They fly and roost in the environment of mountains at altitudes over $5000 \mathrm{~m}$ in unfavourable weather conditions. They show a flexible response to the wind direction which helps them to overcome the environmental obstacle. Unusual behavioural flexibility of Black Kites to surmount various environmental obstacles on their migration routes seems to be connected with vast breeding territory and may also elucidate a new important wintering area for Black Kites. What is more, Black Kites crossing the Himalayas may have physiological adaptations that remain to be investigated.

\section{Abbreviations}

KDE - kernel density estimate, PFA - post fledging area, TSA - temporary settlement area, DEM - digital elevation model, GPS - global positioning system, SMS - short message service, GSM - groupe special mobile, PCR - polymerase chain reaction., LMM - linear mixed model.

\section{Declarations}

\section{Acknowledgements}

We thank Roman F. Bachtin, Oleg Shiryaev, Stanislav Vyhnal, Valeriy Orgunov and Sudur Orgunov for the cooperation the field.

\section{Ethics approval and consent to participate}

Black Kite trapping and tagging were approved by ...

\section{Consent for publication}

Not applicable for the section.

\section{Availability of data and materials}

The datasets used and/or analysed during the current study are available from the corresponding author on reasonable request

\section{Competing interests}

The authors declare that they have no competing interests.

\section{Funding}


The study was supported by Project 2021ITA31 from University of Veterinary Sciences Brno, Czech Republic

\section{Authors' contributions}

IL, IVK, NGA, SVV conducted the field work including birds tagging. IL and JS wrote that paper and conducted the data analyses with guidance from all co-authors. The authors read and approved the final manuscript.

\section{References}

1. Ferguson-Lees J, Christie DA. Raptors of the World. Helm Identification Guides. London: Christopher Helm; 2001.

2. BirdLife International 2021 Species factsheet: Milvus migrans. Downloaded from http://www.birdlife.org on 10 May 2021.

3. Sergio F, Pedrini P, Marchesi L. Adaptive selection of foraging and nesting habitat by black kites Milvus migrans and its implications for conservation: a multi-scale approach. Biol Conserv. 2003;112:351-62.

4. Tanferna A, López-Jiménez L, Blas J, Hiraldo F, Sergio F. Habitat Selection by Black kite Breeders and Floaters: Implications for Conservation Management of Raptor Floaters. Biol Conserv. 2013;160:1-9.

5. Cortés-Avizanda A, Almaraz P, Carrete M, Sánchez-Zapata JA, Delgado A, Hiraldo F, et al. Spatial heterogeneity in resource distribution promotes facultative sociality in two Trans-Saharan migratory birds. 2011.

6. Panuccio M, Agostini N, Mellone U, Bogliani G. Circannual variation in movement patterns of the Black Kite Milvus migrans migrans: a review. Ethol Ecol Evol. 2013;26:1-18.

7. Dickinson EC, Remsen JV. The Howard andMoore Complete Checklist of the Birds of the World. 4th. Eastbourne, UK: Aves Press; 2013.

8. Clements JF, Schulenberg TS, lliff MJ, Billerman SM, Fredericks TA, Sullivan BL, et al. The eBird/Clements Checklist of Birds of the World: v2019. 2019.

9. Orta J, Marks JS, Garcia E, Kirwan GM. Black Kite (Milvus migrans). In: Billerman SM, Keeney BK, Rodewald PG, Schulenberg TS. Birds of the World. Cornell Lab of Ornithology; 2020.

10. Gill F, Donsker D, Rasmussen P. IOC World Bird List v11.1. IOC World Bird List - version 11.1 worldbirdnames.org. 2021.

11. Dementiev GP, Gladkov NA, Ptushenko ES, Spangenberg EP, Sudilovskaya AM. Birds of the Soviet Union. Roč. 1. Sovetskaya Nauka, Moscow in Russian; 1951. 
12. Stepanyan LS. Conspectus of the Ornithological Fauna of the USSR in Russian. Nauka, Moscow; 1990.

13. Karyakin I. Problem of identifcation of Eurasian subspecies of the Black Kite and records of the Pariah Kite in Southern Siberia, Russia. Raptors Conserv. 2017;34:49-67.

14. Skyrpan M, Literák I. A kite Milvus migrans migrans/lineatus in Ukraine. Biologia (Bratisl). 2019;74:1669-1673.

15. Panter $C T$, Xirouchakis S, Danko Š, Matušík H, Podzemný P, Ovčiariková S, et al. Kites Milvus spp. wintering on Crete. Eur Zool J. 2020;87:591-6.

16. Skyrpan M, Panter C, Nachtigall W, Riols R, Systad G, Škrábal J, et al. Kites Milvus migrans lineatus Milvus migrans migrans/lineatus are spreading west across Europe. J Ornithol. 2021;162(2):317-23.

17. Sergio F, Tanferna A, De Stephanis R, López Jiménez L, Blas J, Tavecchia G, et al. Individual improvements and selective mortality shape lifelong migratory performance. Nature. 2014;515:410-413.

18. Ovčiariková S, Škrábal J, Matušík H, Makoň K, Mráz J, Arkumarev V, et al. Natal dispersal in Black Kites Milvus migrans migrans in Europe. J Ornithol. 2020;161:935-51.

19. Hoyo J, Elliott A, Sargatal J. Handbook of the Birds of the World. Roč. 2. Barcelona: Lynx Edicions; 1994.

20. Choudhuri A. Migration of Black-eared or Large Indian Kite Milvus migrans lineatus Gray from Mongolia to North-Eastern India. J Bombay Nat Hist Soc. 2005;102:229-30.

21. Davaasuren B. Khurkh Bird Ringing Station Annual Report 2018. Ulaanbaatar: Wildlife Science Conservation Center of Mongolia; 2019.

22. NIBR National Institute of Biological Resources. National Institute of Biological Resources; 2011.

23. Hirano T, Ueda M. Black Kite Milvus migrans in Japanese. Bird Res News. 2011;810:1-6.

24. Marchant S, Higgins PJ. Handbook of Australian, New Zealand and Antarctic Birds, Volume 2: Raptors to Lapwings. Oxford: Oxford University Press; 1993.

25. Clark B, Davies R. African Raptors, Helm Identigication Guides. London: Bloomsbury Publishing PLC; 2018.

26. Smith D, Ehlers Smith Y, Hoffman B, Downs $C$. in press Home range, landscape use and a migration event by a nonbreeding Yellow-billed Kite Milvus migrans parasitus. Afr J Ecol. 2021;

27. Literák I, Balla M, Vyhnal S, Škrábal J, Peške L, Chrašč P, et al. Natal dispersal of Black Kites from Slovakia. Biologia (Bratisl). 2020;75:591-8. 
28. Popov V. Non breeding concentrations of the Black-eared Kite in the south of Siberia and in Mongolia. Raptors Conserv. 2007;10:57-9.

29. Bakhtin RF. Black Kite in Anthropogenic Landscapes: Monograph in Russian. In: F GBOU VPO „AGAO". Biysk, Russia; 2013.

30. Forero MG, Donázar JA, Hiraldo F. Causes and fitness consequences of natal dispersal in a population the Black Kites. Ecology. 2002;83:858-72.

31. Literák I, Ovčiariková S, Vyhnal S, Škrábal J, Peške L, Rak D, et al. Rodinný přiběh luňáka hnědého. Jak Vlasta, její bratr a její potomci putovali do Afriky (A family story of the Black Kite How Vlasta, her brother and her offsprings travelled to Africa, in Czech). Ptačí Svět. 2021;(28):18-9.

32. Mellone U, Yáñez B, Limiñana R, Muñoz AR, Pavón D, González JM, et al. Summer staging areas of non-breeding Short-toed Snake Eagles Circaetus gallicus. Br Birds. 2011;58:516-21.

33. Vansteelant WMG. An ontogenetic perspective on migration learning and critical life-history traits in raptors. In: Abstracts of British Ornithologists' Union 2019 Annual Conference Tracking Migration: drivers, challenges and consequences of seasonal movements. UK: University of Warwick; 2019. s. 45-6.

34. Onrubia Baticón A. Patrones espacio-temporales de la migración de aves planeadoras en el Estrecho de Gibraltar = Spatial and temporal patterns of soaring birds migration through the straits of Gibraltar.Doctoral thesis. Universidad de León; 2015

35. Literák I, Ovčiariková S, Škrábal J, H. M, Raab R, Spakovszky P, et al. Weather-influenced watercrossing behaviour of black kites Milvus migrans during migration. Biologia (Bratisl). 2021;76(4.):126773.

36. Berezovikov NN. Observation of Black Kite Milvus migrans lineatus in November in Alakolskoya Kotlovina, in Russian. Russ Ornithol J Russ. 2012;737:555-7.

37. Berezovikov NN. Winter observation of Black Kite Milvus migrans lineatus in Almaty, in Russian. Russ Ornithol J Russ. 2014;1082(3981).

38. Romanovskaya IR, Berezovikov NN. Wintering of Black Kite Milvus migrans in Tchuyskaya Dolina, Northern Tien-Shan, In Russian. Russ Ornithol J Russ. 2020;1088:4945-7.

39. Sklyarenko S, Gavrilov E, Gavrilov A. Migratory flyways of raptors and owls in Kazakhstan according to ringing data. Vogelwarte. 2002;41:263-8.

40. Probst R, Pavličev M. migration in the Novosibirsk region and the Kuznetsky Alatau, Russia. Sandgrouse. 2006;28:114-8. 
41. Harris T. Migration Hotspots. The World's Best Bird Migration Sites. London, New Delhi, New York, Sydney: Bloomsbury; 2013.

42. Kumar N, Gupta U, Jhala YV, Qureshi Q, Gosler AG, Sergio F. GPS-telemetry unveils the regular highelevation crossing of the Himalayan by a migratory raptor: implications for definition of a "Central Asian Flyway". Sci Rep. 2020;10(15988).

43. Juhant MA, Bildstein KL. Raptor Migration across and around the Himalayas. In: Prins HHT, Namgail T, editoři. Bird Migration Across the Himalayas. Cambridge: Cambridge University Press; 2017; 98-116.

44. Rotics S, Kaatz M, Resheff YS, Turjeman SF, Zurell D, Sapir N, et al. The challenges of the first migration: movement and behaviour of juvenile vs. adult white storks with insights regarding juvenile mortality. J Anim Ecol. 2016;85:938-47.

45. Vidal-Mateo J, Mellone U, López-López P, De La Puente J, García Ripollés C, Bermejo A, et al. Wind effects on the migra tion routes of trans-Saharan soaring raptors: geographical, seasonal and interspecific variation. Curr Zool. 2016;62:89-97.

46. Safi K, Kranstauber B, Weinzierl R, Griffin L, Rees EC, Cabot D, et al. Flying with the wind: scale dependency of speed and direction measurements in modelling wind support in avian flight. Mov Ecol. prosinec 2013;1(1):4.

47. Green M, Alerstam T, Clausen P, Drent R, Ebbinge BS. Dark bellied Brent Geese Branta bernicla bernicla, as recorded by satellite telemetry, do not minimize flight distance during spring migration. Ibis. 2002;1441:106-21.

48. Malmiga G, Nilsson C, Bäckman J, Alerstam T. Interspecific com parison of the flight performance between sparrowhawks and com mon buzzards migrating at the Falsterbo peninsula: a radar study. Curr Zool. 2014;605:670-9.

49. Vansteelant WMG, Bouten W, Klaassen RHG, Koks BJ, Schlaich AE, Diermen J, et al. Regional and seasonal flight speeds of soaring migrants and the role of weath er conditions at hourly and daily scales. J Avian Biol. 2015;46:25-39.

50. Dodge S, Bohrer G, Weinzierl R. MoveBank track annotation project: linking animal movement data with the environment to discover the impact of environmental change in animal migration. In: Janowicz K, Kessler C, Kauppinen T, Kolas D, Eds SS, editoři. Workshop on GIScience in the Big Data Age in conjunction with the seventh International Conference on Geographic Information Science 2012 GIScience, Columbus OH. 2012; 35-41.

51. Andreyenkova NG, Andreyenkov OV, Karyakin Z IV, I.F. New haplotypes of the mitochondrial gene cytB in the nesting population of the Siberian Black Kite Milvus migrans lineatus Gray, 1831 in the territory of the Republic of Tyva. Dokl Biochem Biophys. 2018;482:242-4. 
52. Kemp MU, Emiel van Loon E, Shamoun-Baranes J, Bouten W. RNCEP: global weather and climate data at your fingertips: RNCEP. Methods Ecol Evol. únor 2012;3(1):65-70.

53. Team RC. R: A language and environment for statistical computing. R 739 Foundation for Statistical Computing [Internet]. Vienna, Austria; 2018. https://www.R-project.org/.

54. Bates D, Maechler M, Bolker B, Walker S. Fitting linear mixed-effects models using Ime4. J Stat Softw. 2015;67:1-48.

55. Burnham KP, Anderson DR. Model Selection and Multimodel Inference: A Practical InformationTheoretic Approach. second. New York, NY, USA: Springer; 2002.

56. Andreyenkova NG, Karyakin IV, Starikov IJ, Sauer-Gürth H, Literák I, Andreyenkov O, et al. Phylogeography and demographic history of the Black Kite Milvus migrans, raptor widespread in Eurasia, Australia and Africa. J Avian Biol. 2021;

57. Lindholm A, Forsten A. Black Kites Milvus migrans in Russian Altai. Caluta. 2011;2:1-6.

58. Dixon A, Rahman L, Sokolov A, Sokolov V. Peregrine Falcons crossing the "Roof of the World". In: Prins HT, Namgail T Eds Bird Migration Across the Himalayas, Wetland Functioning Amidst Mountains and Glaciers. Cambridge: Cambridge University Press; 2017;128-41.

59. Scott GR, Hawkes LA, Frappell PB, Butler PJ, Bishop CM, Milsom WK. How Bar-Headed Geese Fly Over the Himalayas. Physiology. 2015;30(2):107-15.

60. Parr N, Bearhop S, Douglas DC, Takekawa JY, Prosser DJ, Newman SH, et al. High altitude flights by ruddy shelduck Tadorna ferruginea during trans-Himalayan migrations. J Avian Biol. 2017;48:1310-5.

61. Hawkes LA, Balachandran S, Batbyar N, Butler PJ, Chua B, Douglas DC, et al. The paradox of extreme high-altitude migration in bar-headed geese Anser indicus. Proc R Soc B. 2013;280:20122114(1-8).

62. Bishop CM, Spivey RJ, Hawkes LA, Batbayar N, Chua B, Frappell PB, et al. The roller coaster flight strategy of bar-headed geese conserves energy during Himalayan migrations. Science. 2015;347:250-4.

63. Hawkes LA, Balachandran S, Batbayar N, Butler P, Frappell PB, Milsom WK, et al. The trans-Himalayan flights of bar-headed geese (Anser indicus). PNAS. 2011;108:95169.

64. Guo-Gang Z, Dong-Ping L, Yun-Qiu H, Hong-Xing J, Ming D, Fa-Wen Q, et al. Migration routes and stopover sites determined with satellite tracking of Bar-headed Geese Anser indicus breeding at Quinghai Lake, China. Waterbirds. 2011;34:002-116.

65. Namgail T, Takekawa JY, Balachandran S, Palm EC, Mundkur T, Vélez VM, et al. Himalayan thoroughfare: migratory routes of ducks over the rooftop of the World. In: Prins HT, Namgail T Eds Bird 
Migration Across the Himalayas, Wetland Functioning Amidst Mountains and Glaciers. Cambridge: Cambridge University Press; 2017; 30-44.

66. Higuchi H, Minton J. Migratory routes across the Himalayas used by Demoiselle Cranes. In: Prins HT, Namgail T Eds Bird Migration Across the Himalayas, Wetland Functioning Amidst Mountains and Glaciers. Cambridge: Cambridge University Press; 2017;45-57.

67. Agostini N, Pannucio M, Pasquaretta C. Morphology, flight performace, and water crossing tendencies of Afro-Palearctic raptors during migration. Curr Zool. 2015;61:951-8.

68. Batbayar N, Lee H. Steppe Eagle Migration from Mongolia to India. In: Prins HT, Namgail T Eds Bird Migration Across the Himalayas, Wetland Functioning Amidst Mountains and Glaciers. Cambridge: Cambridge University Press; 2017; p. 117-27.

69. Altshuler D, Dudley R. The physiology and biomechanics of avian flight at high altitude. Integr Comp Biol. 2006;46:62-71.

70. Santos CD, Hanssemn F, Muñoz AR, Onrubia A, Wikelski M, May R, et al. Match between soaring modes of black kites and the fine-scale distribution of updrafts. Sci Rep. 2017;7(6421).

71. Ohlmann K. The wind system in the Himalayas: From a Bird's-Eye View. In: Prins HT, Namgail T Eds Bird Migration Across the Himalayas, Wetland Functioning Amidst Mountains and Glaciers. Cambridge: Cambridge University Press; 2017. p 9-28.

72. Heise R. Birds, Gliders and Uplift Systems over the Himalayas. In: Author DL, Prins H, Namgail T, editori. Bird Migration across the Himalayas: Wetland Functioning amidst Mountains and Glaciers. Cambridge: Cambridge University Press; 2017. p. 229-40.

73. Harel R, Getz W, R N. Decision-making by a soaring bird: time, energy and risk considerations at different spatiotemporal scales. Philos T Roy Soc B. 2016.

74. Butler RW, Williams TD, Warnock N, Bishop MA. Wind assistance: a requirement for migration of shorebirds? Auk. 1997;114:456-66.

75. Santos CD, Silva JP, Muñoz AR, Onrubia A, Wikelski M. The gateway to Africa: What determines sea crossing performance of a migratory soaring birds at the Strait of Gibraltar. J Anim Ecol. 2020;89:131728.

76. Nunes G, Hoffmann LS, Macena BCL, Bencke GA, Bugoni L. A Black Kite Milvus migrans on the Saint Peter and Saint Paul Archipelago. Braz Rev Bras Ornitol. 2015;23:31-5.

77. Barcelos LMD, Rodrigues P, Bried J, Mendonça EP, Gabriel R, Borges PAV. Birds from the Azores: An updated list with some comments on species distribution. Biodivers Data J. 2015. https://doi.org/10.3897/BDJ.3.e6604. 
78. Pétursson G, Kolbeinsso Y. Black Kites in Iceland. The Icelandic birding pages. 2018. Available: https://notendur.hi.is/yannk/status_milmig.html.

79. Kumerloeve H. Vom Überwintern des Schwarzmilans im vorderen Orient. Falke. 1967;14:274-27.

80. Baumgart W, Kasparek M, Stephan B. Die Vögel Syrien: eine Übersicht. Heidelberg: Max Kasparek Verlag; 1995.

81. Tsvelykh AN, Panyushkin VE. Wintering of the Black Kite Milvus migrans in Ukraine. 2002.

82. Sarà M. The colonisation of Sicily by the Black Kite Milvus migrans. J Raptor Res. 2003;37:167-72.

83. Domashevskii SV. First record of the Black Kite in winter in the northern part of Ukraine. Berkut. 2009;18:212-3.

84. Ciach M, Kruszyk R. Foraging of White Storks Ciconia ciconia on rubbish dumps on nonbreeding grounds. Waterbirds. 2010;33:101-4.

85. Biricik M, Karakaş R. Black Kites Milvus migrans winter in Southeastern Anatolia. Turk J Raptor Res. 2011;45:370-3.

86. Literák I, Horal D, Alivizatos H, Matušík H. Common wintering of black kites Milvus migrans migrans in Greece, and new data on their wintering elsewhere in Europe. Slovak Raptor J. 2017;11:91-102.

87. Shirihai H, Yosef R, Alon D, Kirwan GM, Spaar R. Raptor migration in Israel and the Middle East. In: International Birdwatching Centre Eilat IBRCE, IOC, SPN. 2000.

88. Forsman D. Identifcation of Black-eared Kite. Bird World. 2003;16:156-216.

89. Abuladze A. Birds of Prey of Georgia, Materials towards a Fauna of Georgia, Issue VI. Tbilisi: Tbilisi. Institute of Zoology, llia State University; 2013.

90. Brooke RK. The migratory Black Kite Milvus migrans migrans Aves: Accipitridae of the Palearctic in southern Africa. Durb Mus Novit. 1974;10:53-66.

91. Forsman D. Flight identifcation of raptors of Europe. North Africa and the Middle East. London: Christopher Helm; 2016.

\section{Tables}

Due to technical limitations, table 1-6 is only available as a download in the Supplemental Files section.

\section{Figures}




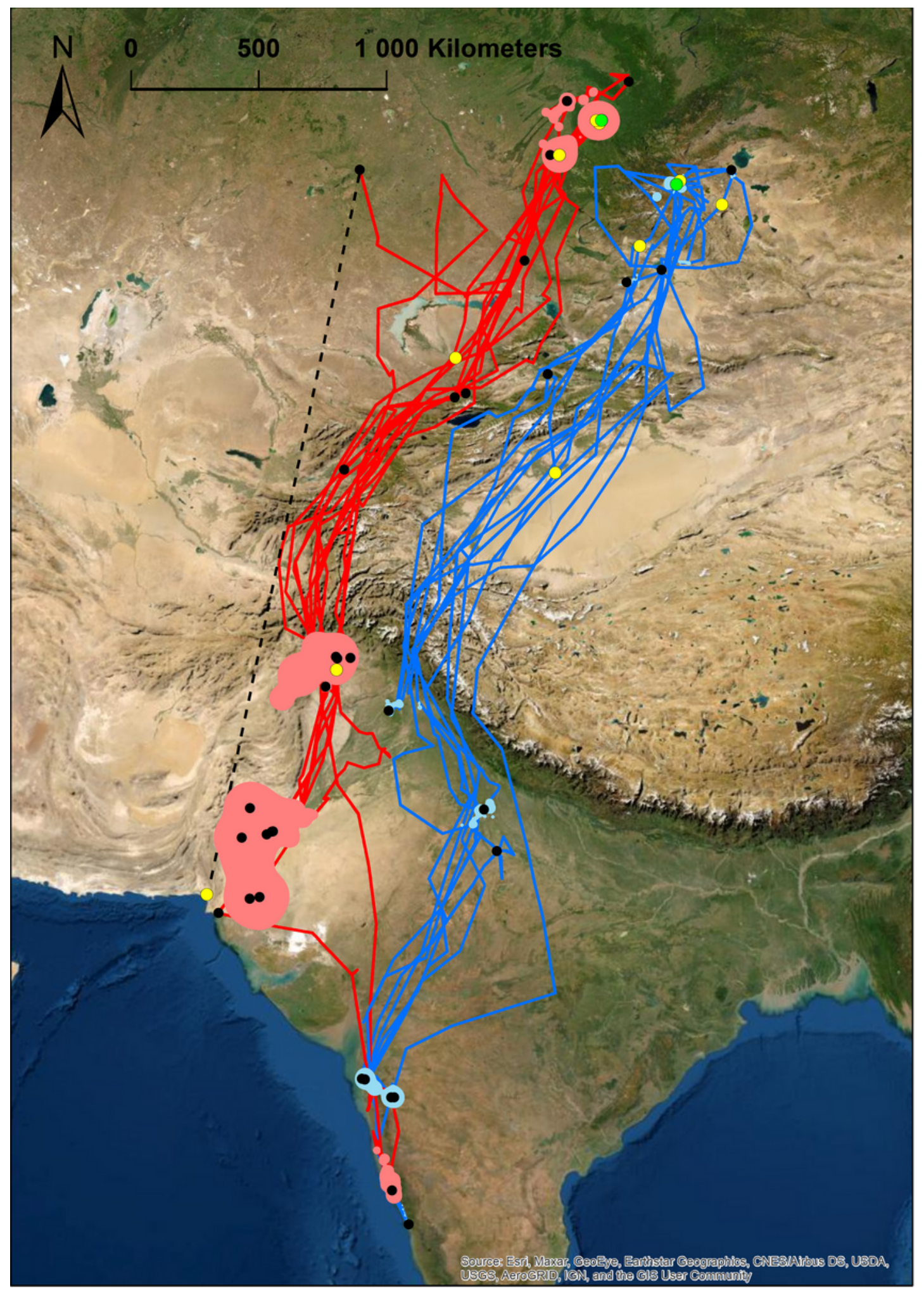

\section{Figure 1}

Migration routes and pre-breeding and post-breeding home ranges of Black Kites tagged in Biysk (red lines and rose polygons) and Kosh-Agach (dark blue lines and light blue polygons). Black dots represent temporary settlement areas. Green dots represent natal nests, yellow dots represent last recorded positions. Black dashed line represents the link between positions of $\mathrm{K} 5$ before and after a gap in data collection. 


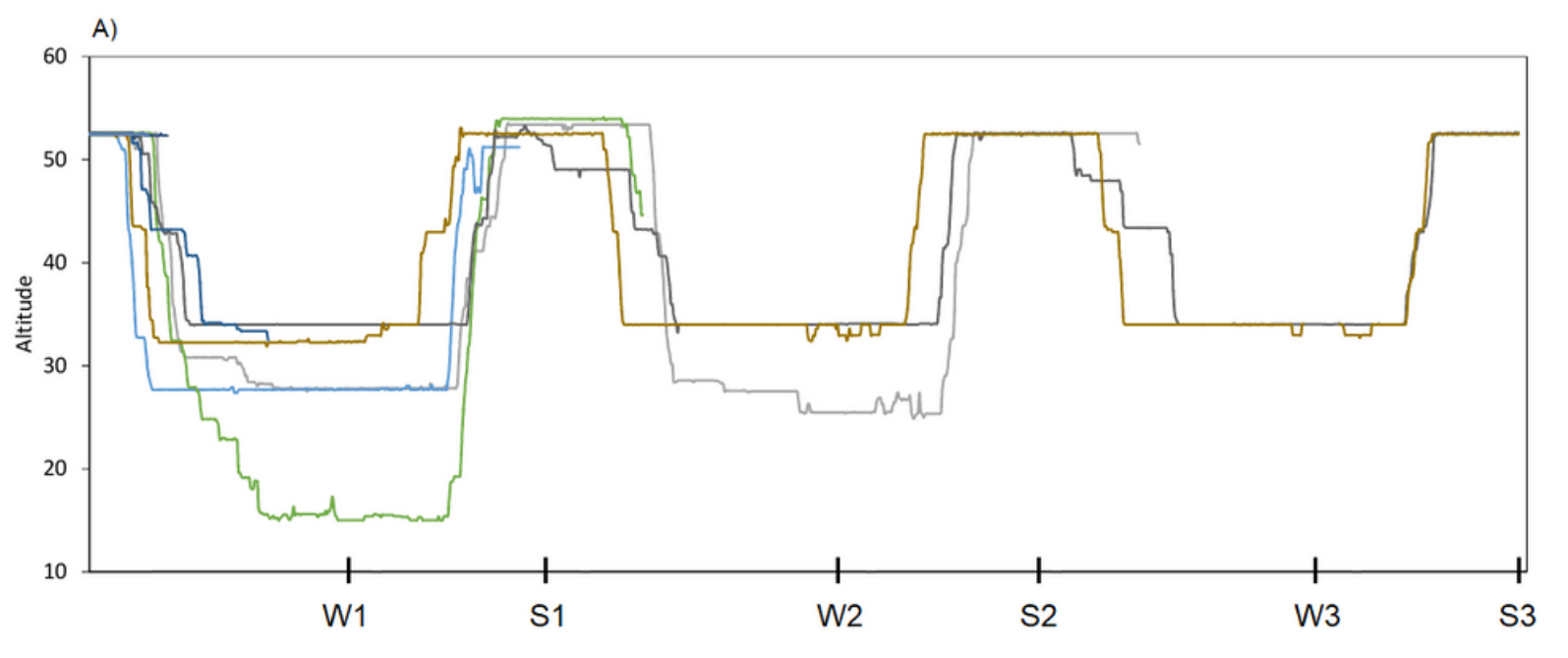

$$
\begin{aligned}
& -\mathrm{K} 1 \\
& -\mathrm{K} 2 \\
& -\mathrm{K} 3 \\
& -\mathrm{K} 4 \\
& -\mathrm{K} 5 \\
& -\mathrm{K} 6 \\
& -\mathrm{K} 7 \\
& -\mathrm{K} 8 \\
& -\mathrm{K} 9 \\
& -\mathrm{K} 10 \\
& -\mathrm{K} 11 \\
& -\mathrm{K} 12 \\
& -\mathrm{K} 13
\end{aligned}
$$

B)

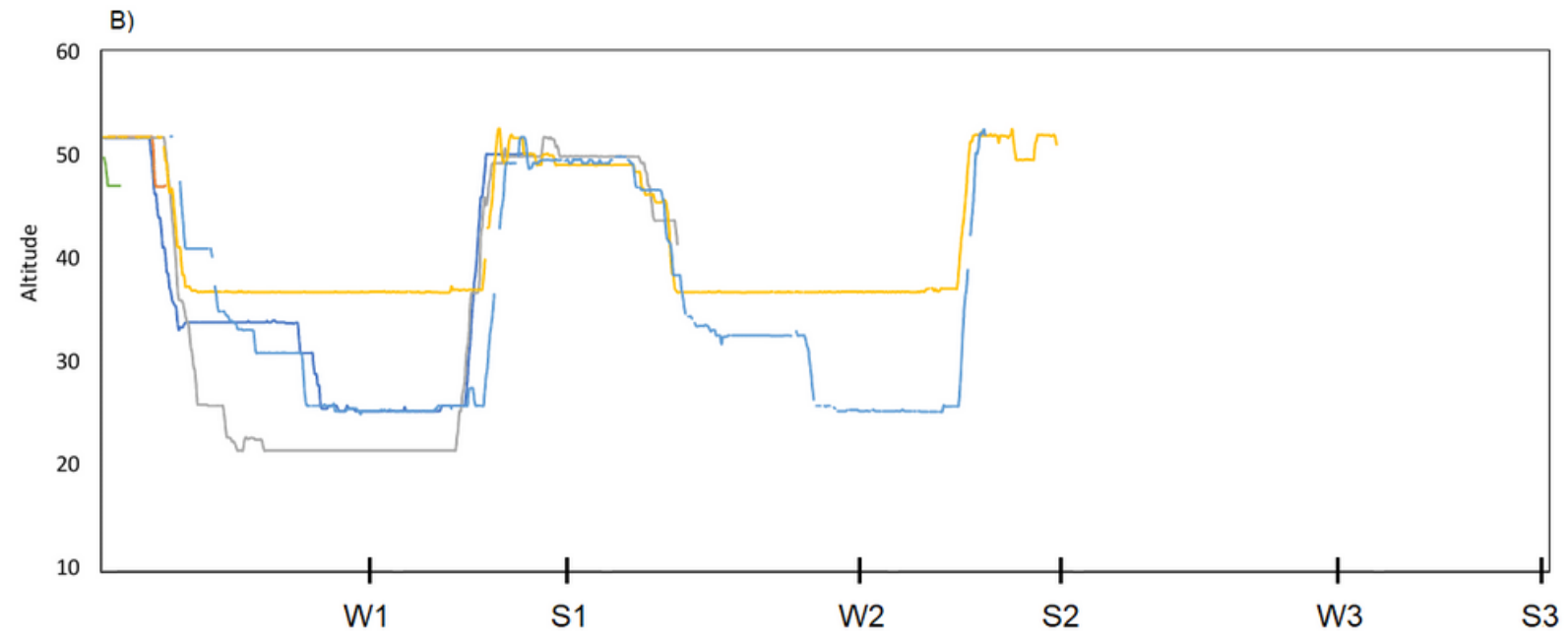

\section{Figure 2}

Latitudinal occurrences of tracked Black Kites throughout their lifespan. W1, W2 and W3 refer to the location of birds on 31 January in 2cy, 3cy and 4cy, respectively; S1, S2 and S3 refer to the location of birds on 30 June in 2cy, 3cy and 4cy, respectively. A, Black Kites from Biysk (lowland in southwestern Siberia); B, Black Kites from Kosh-Agach (Upper Altai). 


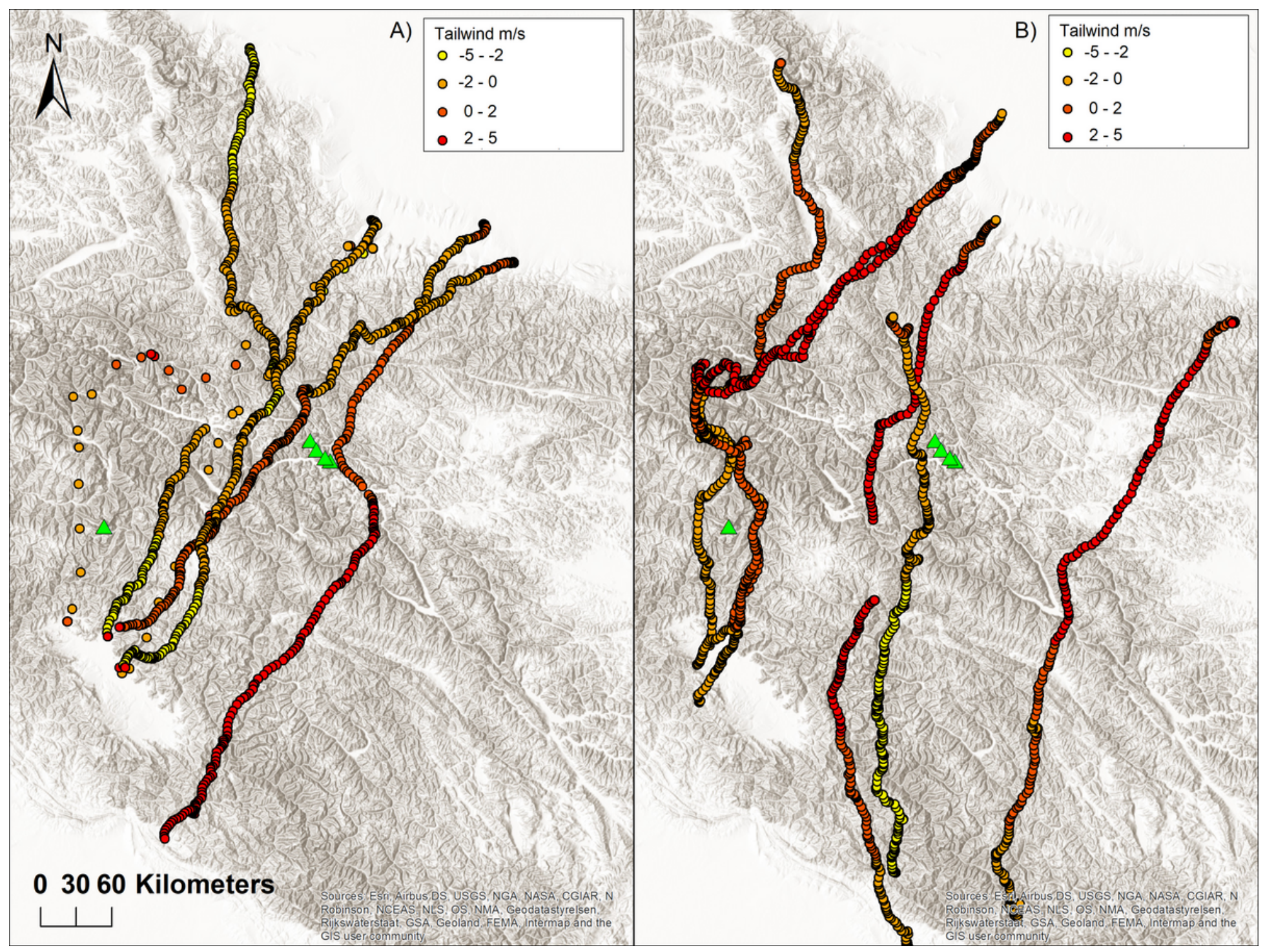

Figure 3

Elevation profile of lifelong journeys of tracked Black Kites. Green dots represent the nest, red dots represent highest roost points during migrations, yellow dots represent the last position collected due to the death of birds or signal loss, blue dots represent the last position collected of living birds. For W1, W2, W3 and S1, S2, S3 see Fig. 2 


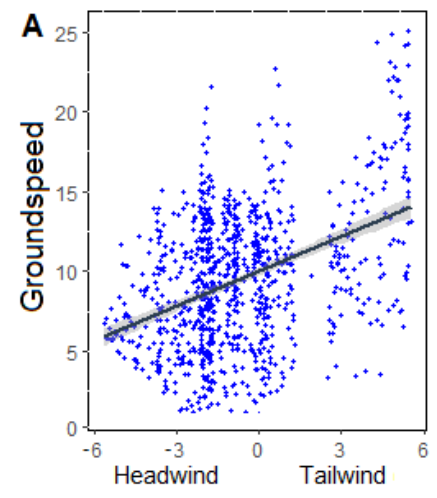

Flow- assistance

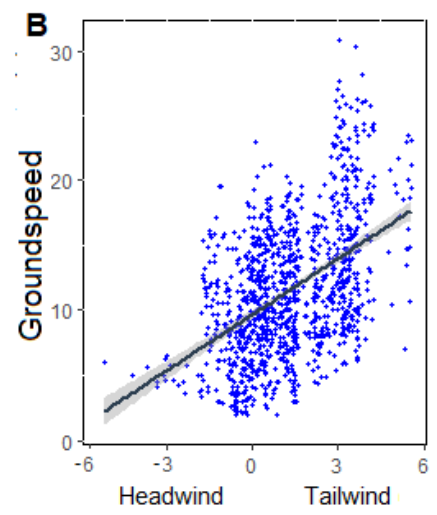

Flow- assistance

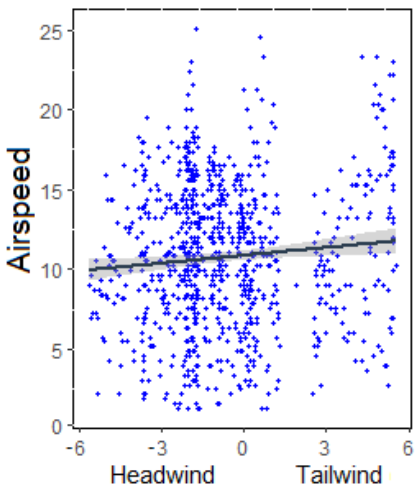

Flow- assistance

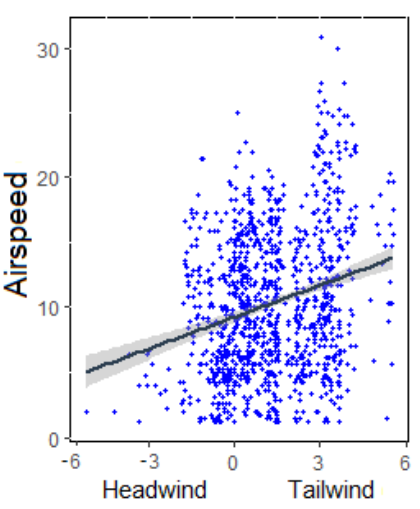

Flow-assistance

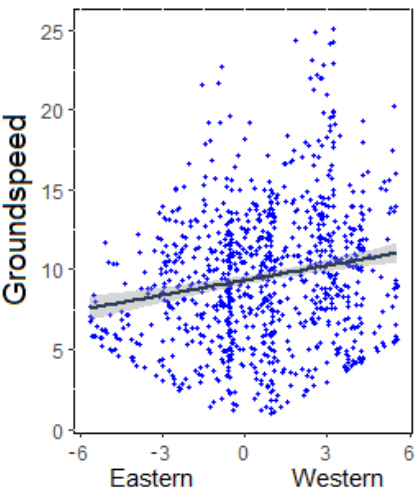

Sidewind

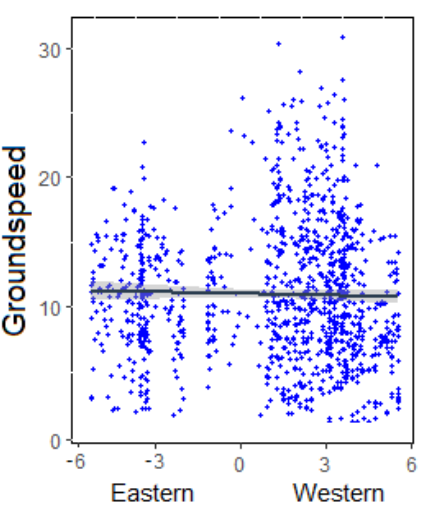

Sidewind
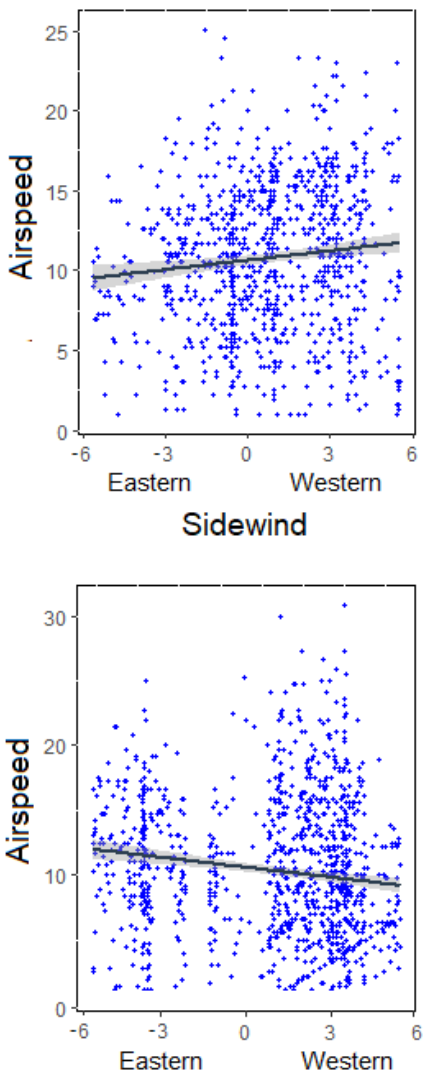

Sidewind

\section{Figure 4}

Post-breeding (A) and pre-breeding (B) flight over the Himalayas in relation to tailwind speed. Green triangles represent mountain peaks over $8000 \mathrm{~m}$. 

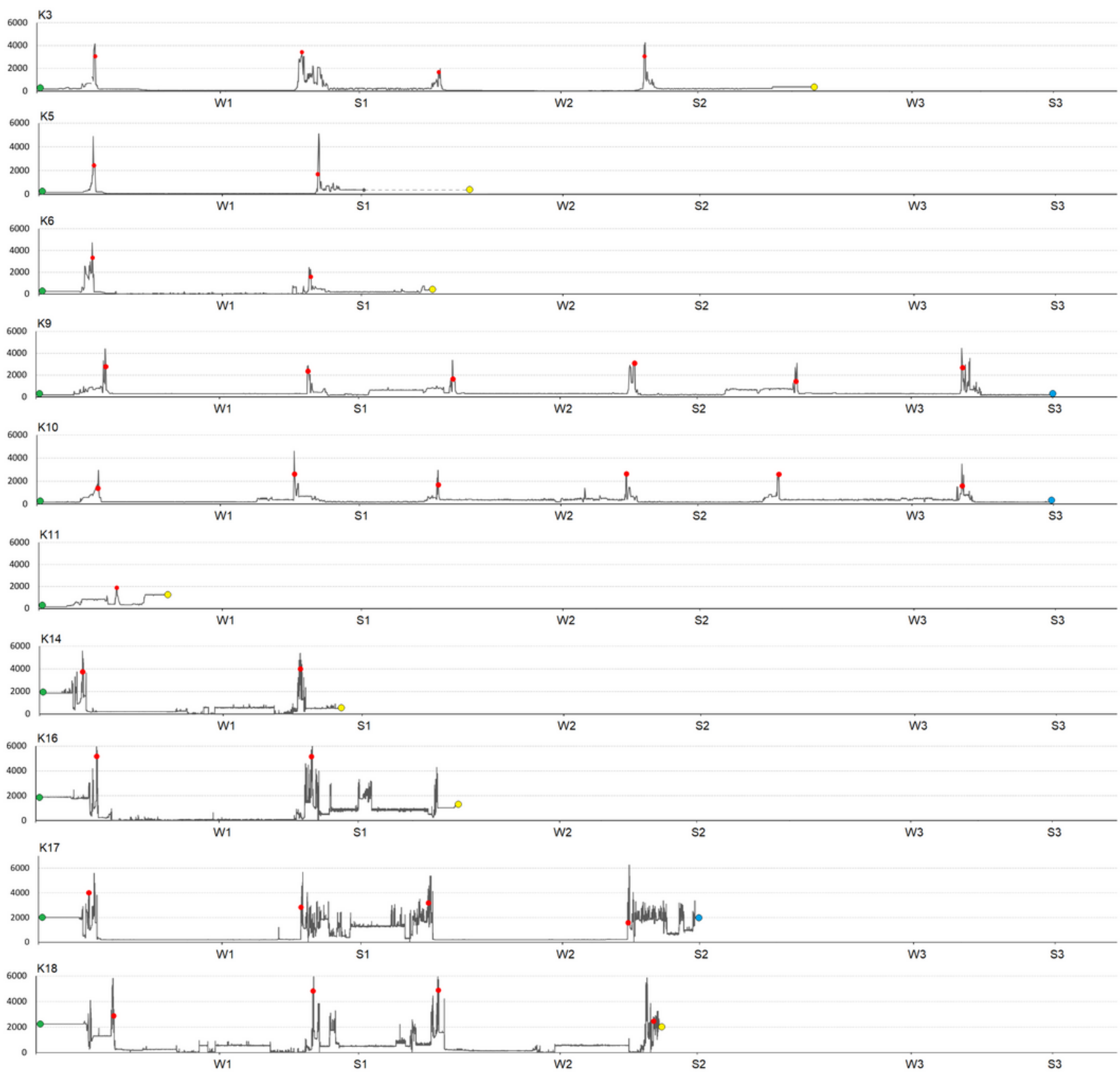

Figure 5

Black Kites groundspeed and airspeed fitted with linear regression lines (grey areas $95 \% \mathrm{Cl}$ ) in relation to side wind and flow-assistance during the post-breeding $(A)$ and pre-breeding (B) flight over the Himalayas.

\section{Supplementary Files}

This is a list of supplementary files associated with this preprint. Click to download.

- Table1.pdf

- Table2.pdf 
- Table3.pdf

- Table4.pdf

- Table5.pdf

- Table6.pdf 